\title{
THE APPLICATION OF MARKOV'S STOCHASTIC PROCESSES IN RISK ASSESSMENT FOR ACCOUNTING INFORMATION SYSTEMS ${ }^{1}$
}

\author{
Ivan Milojević2 ${ }^{2}$ Svetlana Ignjatijevićc ${ }^{3}$ Ivan Mičićc ${ }^{4}$
}

\begin{abstract}
Almost all processes in the area of business management, especially those of determining reliability of the accounting-information system in business management are connected with certain risk, i.e. they are of a stochastic character, which means that every method for solving these problems must be related to the probability theory and corresponding mathematical-statistical methods. This is why it can be noted that only reliable means for determining the reliability rate of the accounting information system are corresponding mathematical-statistical methods. Having this in mind, in this paper we tried to have the problem of forming the risk rate in the area of reliability of the accounting system solved by applying methods based on stochastic processes of Markov's type.
\end{abstract}

Key words: accounting-information system, Markov's stochastic processes, financial reporting

JEL: M41, Q13.

\section{Introduction}

One of the basic functions of the accounting information system is to provide the biggest rate of reliability for the business subject it is implemented in, i.e. to decrease risk of damage from errors which can occur when there is a difference in the amount that valued a business change that happened with the one that was entered in business records. In order for business subjects to be able to fulfill this function completely, they must posses the necessary information on the state of funds required to satisfy business

1 This paper is the product of VA-DH5/17-19.

2 Ivan Milojević Ph.D., Full Professor, University of Defence, Military Academy, Pavla Jurišića Šturma street no. 33, 11000 Belgrade, Republic of Serbia, Phone: 0038160070 2697, E-mail: drimilojevic@gmail.com.

3 Svetlana Ignjatijević Ph.D., Associate Professor, University Business Academy, Faculty of Economics and Engineering Management in Novi Sad, Cvećarska street no. 2, 21000 Novi Sad, Republic of Serbia, E-mail: svetlana.ignjatijevic@gmail.com.

4 Ivan Mičić M.A., Ph.D. student, University in Belgrade, Faculty of Agriculture, Nemanjina street no. 6, 11080 Zemun, Serbia, Phone:+381 6297311 58,E-mail: divanlav@gmail.com

EP 2017 (64) 2 (551-560) 
obligations as well as regular operations and functioning of the same organization, at their disposal at every moment. Considering that business organizations have an organized accounting-information system where the biggest amount of information is provided by the application of corresponding accounting processes, which are formed based on previously determined accounting concepts, principles and procedures, the problem of assessing the reliability risk of accounting information system is one of the most significant problems for every organization that bases its business management on market principles (Backović, Vuleta, 2002). The fundamental problem that needs to be solved is that, within the framework of reliability of the accounting-information system, it's necessary to provide for the reliability risk to be as low as possible, and for recording the value of funds and capital i.e. accounting changes that are led in business records as a part of the accounting system, to have a certain reliability rate of evaluating inputs in the accounting information system which needs to be done in advance, i.e. in current time, but in a way to secure sufficient qualitative and quantitative reliability for their application in the future i.e. when making financial reports in a given or presumed time period, which in practice is usually one year, to be able to make business decisions which are based on accounting information (Buhlmann, 1970). This means that for determining the reliability rate of the accounting-information system in every business subject, and especially in subjects that do business in market economies, it is necessary to make certain forecasts which represent an assessment of the state or size of a certain occurrence or indicator in the future based on known states or sizes for this occurrence or indicator in the past. It is normal for the forecast or assessment of future states or sizes to be linked to certain uncertainty and risk, as are most occurrences and processes in the accounting systems (Mihajlović, 2016).

This is why different methods (Stanojević et al., 2017) and processes are used for addressing these problems, and the ones that are especially applicable are mathematicalstatistical methods which with certain limitations and assumptions, give scientific worth and verification to such determined forecasts and assessments.

\section{Forming the reliability rate of the accounting risk}

In current practice following methods and processes were used for determining the risk rate of the accounting-information system, i.e. for harmonization of accounting data value:

- determining value based on experience,

- correction of existing values by using an applicable technical result and

- determining value by applying different mathematical-statistical methods.

Determining value of accounting information based on experience is applied in cases for which there is no suitable statistical data on asset value, or any other significant indicators for financial reporting. In that case an individual or a certain group of people assesses the value of assets. It is evident that this process isn't based on the application of any objective scientific method, but completely of a subjective character which 
represents its basic shortage, and should be avoided in practice (Kočović, 1993).

Correction of existing accounting values by an applicable technical result is done periodically with a goal to avoid huge losses or make unjustified abnormal profits for a business organization.

Good feature of this process is in that it can establish whether the degree of harmonization used in a long time period was adequate, by determining the technical result.

The basic shortcoming in applying the process of technical results for correcting existing values of accounting information (Aureo, 2016) is in the fact that it isn't adequate for application in accounting-information systems in which there are possibilities of large standard deviations occurring, because large standard deviations almost always deviate the real picture on the quality of assessment of the accounting risk.

Due to the fact that almost all processes in the area of accounting risk, especially those in determining the reliability of the system, are connected to uncertainty, i.e. they are of stochastic character, every method for determining the value of accounting information must be based on the probability theory and corresponding mathematical-statistical methods, so that it can be easily noted that, for determining the value of accounting information (Hall, 2013), i.e. the risk degree of accounting-information system, only reliable means are the corresponding mathematical-statistical methods.

When applying these methods, values of accounting data determined need to be such that, they satisfy certain specific demands which depend on specific conditions and types of accounting as well as the following conditions:

- Creation of accounting risk, i.e. the value of accounting data which are adequate to the values presented in financial reports;

- Creation of corresponding methodology which includes all relevant data and indicators necessary for calculating values of accounting information and

- Creation of suitable methodology for tracking expenses of implementing this process.

When determining the value of accounting information (Romney, Steinbart,2014) by applying any mathematical-statistical method, we started from a basic principle which is called the principle of equivalence. This principle can be formulated in the following way: the sum of values that are presented in financial reports in a certain time period are compensated with accounting data which is periodically entered in the accounting-information system or put differently, by applying a corresponding mathematical-statistical method the value determined needs to be such that it will enable the compensation of accumulated amounts in a predetermined time period (Mamić-Sačer, Žager, 2007). Translated in mathematics it can be said that the value of accounting information depends on the distribution of input data value. If the value of accounting data is marked with $P$, and the distribution of value in financial reports with $G_{s}(x)$, then the aforementioned dependence can be expressed with the following 
functional dependence

$$
P=f\left[G_{s}(x)\right]
$$

which means that by using the $f$ function, a certain amount of accounting data $P$ is assigned to every demand function of financial reports $G_{s}(x)$.

When assessing the accounting risk, and with it forming the reliability degree of the accounting-information system, i.e. for determining the value of accounting data or accounting information in financial reports, different mathematical-statistical methods can be used, and in current practice the following methods were used most often:

- Heuristic methods;

- Methods of trend extrapolation;

- Regression and correlation analysis methods;

- Mathematical modeling methods;

- Methods based on stochastic processes and specially on processes of Markov's type;

- Simulation methods;

- Methods based on fuzzy sets and fuzzy logics, and many other.

Each of these methods has its positive and negative feature which is analyzed and processed in voluminous and rich literature from this field, in detail (Vuleta et al., 2013). This is why we will not dwell on stating the characteristic and examining conditions and possibilities of their application here, but will devote our attention to problems of risk assessment of the accounting-information system in the area of business subject's accounting, by applying methods based on stochastic processes of Markov's type.

\section{Changing the value of accounting data as markov's stochastic process}

Theory of stochastic processes deals with classification of processes and examination of certain functional dependencies between future states of processes and factors that determine them. The term "process" here defines a complex of events that are interlinked in a certain way, and the events themselves determine the state of the process in each time period.

One of the most significant classes of stochastic processes is made of the so-called Markov's processes. The basic characteristic of Markov's processes is seen in that, the probability that $p_{i j}$ will cross from its current state $i$ into some future state $j$ doesn't depend on how the process came into state $i$, or how the process occurred before coming into state $i$. This means that this probability only depends on the state $i$ in which the process can be found in the given time period and the state $j$ in which the process will be found after a certain period of time passes.

In reality there are almost no pure Markov's type processes, but rather a large number 
of stochastic processes which can be approximated by the process of Markov's type for multiple reasons. This is where we will presume that the movement of reliability risk value of the accounting-information system fulfils basic prerequisites of Markov's stochastic processes. The reasons for this assumption can be explained in the following way:

1. Future values in financial reports of the accounting-information system (Kay, Ovlia, 2013) depend on current value size of accounting data, and less on the value size of accounting data from previous time, i.e. accounting periods (years). In previous time periods the value of accounting data had mostly growth tendencies until it reached its current state, so the future values of accounting data depends more on its current value rather than values from previous time periods (years).

2. Considering that this is about determining reliability risk value of the accountinginformation system in relation to showing the value of information presented in financial reports, the value of that accounting information and with it, the value of data entered in the accounting system will in future time periods depend on the size and value of data which was documented at the start of a business event. Other than that, the value of accounting data as well as the data which was entered in the accounting-information system will depend on the development and state of the economy as a whole, as well as many other factors which have a significant influence on determining the probability of crossing $p_{i j}$. It is evident that these factors have an exclusive impact on the value of accounting data, and with that values which are shown in financial reports, only in the future, not in the past.

Based on this the movement of accounting data values can be treated as one stochastic process of Markov's type, in which the values presented in financial reports in certain years can be considered states of the process. If we take that the period of one year is the time required to cross from one state into another (reporting period), and that the probability $p_{i j}$ represents the probability of accounting data value to cross from the level $i$ to the level $j$ after a one year period passes.

\section{Determining transitive matrices}

Before we move to predicting accounting data values (Vuleta, 1998) for the following lets say $n$ months, the following elements need to be determined:

The base month and the prediction period. Let us presume that in our case it is the null month and that the prediction period is the following five months.

For the given time period it is necessary to determine the lower limit $d$ under which the value of accounting data won't be in any given month. This limit for accounting data value can be determined based on accounting statistic for this type of data in previous time periods, i.e. years.

It is necessary to determine the upper limit $D$ over which no accounting data will go over in any of the following five months. At first glance it can be concluded that it is preferable for this limit to be very high, because that reduces the probability of crossing 
it. However in that case it can happen for the results that depend on that limit not to be acceptable due to an unrealistic assessment. Based on that, the lower limit $d$ and upper limit $D$ need to be determined in the most realistically precise way. This is a job on which experienced accounting and professional experts need to be hired, and the statistical service of insurance organizations (Vuleta et al., 2013)

The space $R=[d, D]$ will be called the trust space. This space has the feature that the accounting data value can't be lower that the lower limit $d$ or higher than the upper limit $D$. According to that, the probability that value of accounting data in the following five months will move within the boarders $[d, D]$ is equal to one.

The space of trust $R=[d, D]$ will be divided into $n$ intervals, which can be different, and every interval will be called the level of accounting data value $i$ where $i=1,2, \ldots n$. The lowest, first level is marked with 1 , the second level with 2, etc. up to $n$ as the highest level of accounting data value.

If the value of accounting data at the end of a certain month is at the level $i$, after the next month elapses, the accounting data value can be found at the same level, or cross to a higher or lower level $j$. This probability that the accounting data value will cross from level $i$ to level $j$ after one year will be marked with $p_{i j}$, where it is possible for $i=j$ (where $i, j=1,2, \ldots, n$ ).

We are not only interested in the probability of accounting data value crossing from level $i$ to level $j$ in a one month period, but where the accounting data value can be found, i.e. what state will the process take after lets say $t$ months. The probability that the accounting data value will be found at level $i$ after $t$ months will be marked with $s_{i}(t)$, where $t=0,1,2, \ldots N$.

With the probability $p_{i j}$ we will form the following matrix.

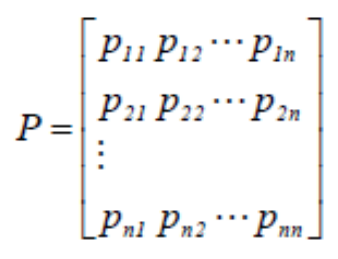

This matrix will be called a transitive matrix, because its elements represent the probability of crossing, and the matrix itself describes movement of accounting data value and has following features:

- It is a square matrix;

- Its elements must be non-negative numbers between zero and one, because they represent probabilities;

- Each row or column of the matrix $P$ represents a vector of probability, which means that the sum of elements in each row (column) of this matrix equals one. 
Considering the probability $s_{i}(t)$, they have to satisfy the condition that

$$
\sum_{i=1}^{n} s_{i}(t)=1, \quad t=1,2, \ldots, N
$$

which means that the accounting data value has to be on one of $i=1,2, \ldots, n$ levels after each month runs out.

Let us observe the starting point of accounting data value, which is the last one at our disposal. Let us consider that this is the level from the null month so for this month, which corresponds to the value $t=0$, the level of accounting data values $i 0$ is known, which means that

$$
S_{i 0}(0)=1
$$

Since the defined values $s_{i}(t)$ are complex, and $p_{i j}$ are conditional probabilities, based on the theorem on complex and conditional probability the following recurrent relation can be written

$$
s_{i}(t+1)=\sum_{i=1}^{n} s_{i}(t) p_{j}, t=0,1,2, . ., N, j=1,2, \ldots, n .
$$

If we define the vector $S(t)$ in the following way

$$
S(t)=\left[s_{1}(t), s_{2}(t), \ldots, s_{n}(t),\right],
$$

then the previous equality can be written in the matrix in the form

$$
S(t+1)=S(t) P, \quad t=0,1,2, \ldots, N,
$$

where $P$ is a transitive matrix.

If we put this relation of values for $t=0,1,2, \ldots$ we will get:

$$
\begin{aligned}
& S(1)=S(0) P, \\
& S(2)=S(1) P=S(0) P^{2}, \\
& S(3)=S(2) P=S(0) P^{3}
\end{aligned}
$$

and so on, or in general case

$$
S(t)=S(0) P^{t}, t=0,1,2, \ldots, N,
$$

where

$$
S(0)=(1,0,0, \ldots, 0)
$$

is a unit vector of $\mathrm{n}^{\text {th }}$ row. 
Vector $S(t)$ gives the layout of probabilities for different levels of accounting data values after the period of $t$ months (Milojević et al., 2012). This layout is got by multiplying the vector $S(0)$ which represents the null state of the process with a transitive matrix $P$ which had a previous exponentiation by an exponent $t$.

Let us defined one number for every of the $n$ levels of accounting data values which will represent it. It is best to take middle of the observed levels, so the row of numbers $v_{1}, v_{2}, \ldots, v_{n}$ is got, which can be observed as the vector $V$ of the $\mathrm{n}^{\text {th }}$ row with coordinates $v_{1}, v_{2}, \ldots, v_{n}$.

Since the layout of probabilities is previously determined on each level for every $t$, so by using the relation

$$
E_{t}=\sum_{i=1}^{n} v_{i} s_{i}(t), \quad t=0,1,2, \ldots N
$$

it is possible to calculate the corresponding expectancy of accounting data values (Tourki, 1991). These expected values can be presented in the form of scalar product of vectors $V$ and $S(t)$, so

$$
E_{t}=[V, S(t)], t=0,1,2, \ldots, N \text {. }
$$

Since for $t=0, v_{i o}(0)=1$, where $i 0$ marks the known accounting data value in the last (null) month for which data exists, those are other probabilities $v_{i}(0)=0$, for $i \neq i 0$. Because of that

$$
E_{0}=s_{i o},
$$

and other values for $E_{t}$ are calculated according to the aforementioned form, when $t$ takes the value from 1 to $N$, where in this case $N=5$. So in the end we get the vector

$$
E=\left[E_{0}, E_{1}, E_{2}, \ldots, E_{N},\right]
$$

which represent future monthly movement of accounting data values.

\section{Conclusion}

In this paper one process based on Markov's stochastic processes was stated, from which all theoretical and methodological aspects of using mathematical-statistical methods for determining accounting data values in the accounting-information system can be perceived, and with that forming risk rate for accounting for this type of accountinginformation system.

However when we talk about the practical use of mathematical-accounting methods for solving concrete problems in accounting, then the possibilities of applying these methods, as well as the quality of given results, greatly depend on the quality and availability of necessary accounting-statistical data. This further means that if a business organization has reliable accounting and statistical material at their disposal, based on which they can perform a comprehensive and precise cause and effect analysis for each type of realized business events, then by concrete application of corresponding 
mathematical-statistical methods in a satisfying way, many problems from the area of assessing the reliability rate can be solved, as well as the problem of assessing risk in the accounting-information system.

As far as for the possibility of practical application of the presented method for forming the risk rate of the accounting-information system, it is necessary to emphasize that greatest attention should be devoted to forming the transitive matrix $\mathrm{P}$, and determining the trust interval $[\mathrm{d}, \mathrm{D}]$. When determining these indicators next to accounting and statistical data from the business subject, other relevant statistical material and data from the market can be used, as well as personal experience, if we talk about a wider accounting-information system.

\section{Refences}

1. Aureo, B. (2016): Desenvolvimento da contabilidade, Oditor, Vol. 2, No. 3, pp. 39-47.

2. Backović, M., Vuleta, J. (2002): Ekonomsko-matematički metodi i modeli, Ekonomski fakultet, Beograd.

3. Buhlmann H. (1970): Mathematical Methods in Risk Teory, Springer Verlak, Berlin, Heidelberg, N.Y.

4. Hall, J.A. (2013): Introduction to Accounting Information Systems, 8th International Edition, Cengage Learning.

5. Kay, D., Ovlia, A. (2013): Accounting Information Systems, Pearson New International Edition, 2nd Edition, 2013.

6. Kočović, J. (1993): Finansijska matematika, Ekonomski fakultet, Beograd.

7. Mamić-Sačer, I., Žager, K. (2007): Računovodstveni informacijski sustavi, Hrvatska zajednica računovođa i financijskih djelatnika, Zagreb.

8. Mihajlović, M. (2016): Odnos menadžmenta preduzeća i korporativnog upravljanja, Oditor, Belgrade, Serbia, Vol. 2, No. 1, pp. 4-10.

9. Milojević, I., Mihajlović, M., Cvijanović M. (2012): Impact of organizational failure of relevance consolidated budget, Ekonomika poljoprivrede, Vol. 49, No. 1, pp. 63-71.

10. Romney, M.B., Steinbart, P.J. (2014): Accounting Information Systems, Global Edition, Pearson, 13th Edition.

11. Stanojević, S., Đorđević, N., Volf, D. (2017): Primena kvantitativnih metoda u predviđanju poslovanja privrednih subjekata, Oditor, Vol. 3, No. 1, pp. 91-101.

12. Tourki, M. (1991): Modeliranje ekonomskih procesa u uslovima stohastičnosti i konflikta, Ekonomski fakultet, Beograd, 1991

13. Vuleta, J. (1998): Prikaz razvoja i primene metoda operacionih istraživanja u ekonomskom sistemu u svetlu SYM-OP-IS-a, Industrija, Vol. 24, No. 1-4, pp. 33-56.

14. Vuleta, J., Andžić, R., Andžić, S., Novaković, S., Krstić, S., Subić, J. (2013): Selection of the best conctractor for realization of each project activity using multi-criteria analysis, Metalurgia international, Vol. 18, No. 10, pp. 69-72 


\title{
PRIMENA MARKOVLJEVIH STOHASTIČNIH PROCESA U PROCENI RIZIKA ZA RAČUNOVODSTVENE INFORMACIONE SISTEME $^{5}$
}

\author{
Ivan Milojević, Svetlana Ignjatijevićc , Ivan Mičic ${ }^{8}$
}

\begin{abstract}
Apstrakt
Praktično svi procesi u oblasti poslovnog menadžmenta, posebno oni koji određuju pouzdanost računovostvenog informacionog sistema u poslovnom menadžmentu su povezani sa određenim rizikom, tj. oni su stohastičnog karaktera, što znači da svaka metoda za rešavanje ovih problema mora da bude povezana sa teorijom verovatnoće $i$ odgovarajućim matematičko-statističkim metodama. To je razlog zašto se može konstantovati da su odgovarajuće matematičko-statističke metode jedina pouzdana sredstva za određivanje stope pouzdanosti računovodstvenog informacionog sistema. Imajući ovo u vidu, autori ovog rada su pokušali da reše problem formiranja stope rizika u oblasti pouzdanosti računovodstvenog sistema primenom metoda baziranih na stohastičkim procesima Markovljevog tipa.
\end{abstract}

Ključne reči:računovodstveni informacioni system, Markovljevi stohastični procesi, finansijsko izveštavanje.

5 Ovaj rad je rezultat projekta VA-DH5/17-19.

6 Redovni profesor, dr Ivan Milojević, Univerzitet odbrane, Vojna akademija, Ulica Pavla Jurišića Šturma br. 33, 11000 Beograd, Republika Srbija, Telefon: 0038160070 2697, E-mail: drimilojevic@gmail.com.

7 Vanredni profesor, dr Svetlana Ignjatijević, Univerzitet Privredna akademija, Fakultet za ekonomiju i inženjerski menadžment, Cvećarska ulica br. 2, 21000 Novi Sad, Republika Srbija, E-mail: svetlana.ignjatijevic@gmail.com.

8 Ivan Mičić M.A., student doktorskih studija, Univerzitet u Beogradu, Poljoprivredni fakultet, Nemanjina ulica br. 6, 11080 Zemun, Srbija, Telefon: +381 6297311 58, E-mail: divanlav@.gmail.com 